\title{
Boron Doped Diamond Electrode for the Wastewater Treatment
}

\author{
Marco Antonio Quiroz Alfaro, ${ }^{a}$ Sergio Ferro, ${ }^{b}$ Carlos Alberto Martínez-Huitle ${ }^{*, b}$ and Yunny Meas Vong ${ }^{c}$ \\ ${ }^{a}$ Departamento de Química y Biología, Escuela de Ciencias, Universidad de las Américas-Puebla, Sta. Catarina \\ Mártir, Cholula 72820 Puebla, México \\ ${ }^{b}$ Department of Chemistry, University of Ferrara, via L. Borsari 46, I-44100 Ferrara, Italy \\ ${ }^{c}$ Centro de Investigación y Desarrollo Tecnológico en Electroquímica S.C. Parque Tecnológico Querétaro Sanfandila, \\ Pedro Escobedo, Querétaro 76700 México
}

\begin{abstract}
Os estudos sobre eletroquímica do diamante iniciaram-se há mais de quinze anos, com o primeiro artigo publicado nessa área, por Pleskov. Depois disso, pesquisas começaram no Japão, Estados Unidos, França, Suíssa e outros países, sendo que nos últimos anos o número de publicações aumentou consideravelmente. Filmes de diamante têm sido o objeto de aplicações e pesquisa fundamental em eletroquímica, abrindo um novo campo conhecido como eletroquímica de eletrodos de diamante. Aqui, nós apresentamos uma breve história e o processo de síntese de filme de diamante. O principal objetivo deste trabalho é resumir os resultados mais importantes em oxidação eletroquímica, usando-se eletrodos de diamante.
\end{abstract}

Electrochemical studies of diamond were started more than fifteen years ago with the first paper on diamond electrochemistry published by Pleskov. After that, work started in Japan, United States of America, France, Switzerland and other countries. Over the last few years, the number of publications has increased considerably. Diamond films have been the subject of applications and fundamental research in electrochemistry, opening up a new branch known as the electrochemistry of diamond electrodes. Here, we first present a brief history and the process of diamond film synthesis. The principal objective of this work is to summarize the most important results in the electrochemical oxidation using diamond electrodes.

Keywords: electrochemical oxidation, diamond electrode, pollutants, efficiency, wastewater treatment

\section{Introduction}

Since the first paper about the electrochemistry of boron doped polycrystalline diamond published by Pleskov et al. ${ }^{1}$ in 1987, the boron-doped diamond (BDD) thin films are found to be particularly attractive for electrolysis and electroanalytical applications due to their outstanding properties, which are significantly different from those of other conventional electrodes, e.g. glassy carbon or platinum electrode. ${ }^{2}$ In addition to innate properties of diamond, such as high thermal conductivity, high hardness and chemical inertness, the attractive features of conductive BDD include a wide electrochemical potential window in aqueous and non-aqueous media, very low capacitance and extreme electrochemical stability. ${ }^{2,3}$

*e-mail: mhuitle@hotmail.it
Diamond exhibits very high overpotentials for the chemical species following the inner-sphere mechanism because of the inertness of the surface for adsorption. ${ }^{4}$ This is the reason it exhibits high overpotentials for the oxygen and hydrogen evolution resulting in a wide electrochemical potential window. While this helps in the electroanalysis of a wide variety of chemical species, the inactiveness of diamond electrode for certain species such as glucose $e^{5,6}$ and $\mathrm{H}_{2} \mathrm{O}_{2}$ necessitates the modification of the diamond electrode with catalysts to activate it. For example, Duo and co-workers ${ }^{7,8}$ showed that the deposition of small amounts of $\mathrm{IrO}_{x}$ clusters on the diamond surface dramatically enhances both the oxygen evolution reaction and the oxidation of organics in the potential region of water decomposition. Chemically modified electrodes have shown advantages over conventional electrodes. 
In previous results, electrochemistry of BDD and its advantages compared to conventional electrodes have been reported for electrochemical oxidation of several important chemical species. The electrochemical oxidation method has been proposed for the destruction and/or the conversion of mixed waste, when the wastewater contains refractory organic pollutants or toxic substances. The principal aim of the wastewater treatment is complete oxidation of organics to $\mathrm{CO}_{2}$ or the conversion of toxic organics to biocompatible compounds..$^{9-12}$

Several studies have been completed, with the goal of developing applications in the electrochemical oxidation of organics for wastewater treatment. Comninellis and coworkers ${ }^{13-15}$ have found that the electrochemical oxidation of most organics in aqueous media occurs only at high potentials, with a concomitant evolution of $\mathrm{O}_{2}$; in addition, the nature of the anodic material strongly influences the process selectivity and efficiency. Hence, a model for the anodic oxidation of organics in acidic media, including competition with oxygen evolution, has been proposed. ${ }^{13-15}$ In this model, the electrochemical and chemical reactivity of the adsorbed hydroxyl radicals are explained, underlining the important role of the nature of the anode material. Depending on the interactions between hydroxyl radicals and the electrode surface, anodes can be distinguished as "active" or "non-active" materials. ${ }^{14-16}$ Among the particular characteristics of BDD, its chemical inertness is well recognized; for this reason, this material is considered an ideal "non-active" electrode on which organics oxidation and oxygen evolution take place through the formation of weakly adsorbed and very reactive hydroxyl radicals.

Based on a literature review, this article summarizes and discusses the recent results available in the literature concerning the application of diamond electrode in electrochemical processes for water treatment. Also a brief introduction about the electrochemical characteristics and other properties of this electrode are presented.

\section{Synthesis of Diamond}

As diamond is the densest allotrope of carbon, at high pressure diamond should be the most stable form of the solid carbon. This reasoning was the basis for the highpressure high-temperature (HPHT) growth techniques that have been used in commercial synthesis for the last 30 years. Much effort has been spent during the 60's and 70's to investigate diamond growth at low pressures. Diamond synthesis was successfully achieved by Chemical Vapor Deposition (CVD) techniques at low pressures. ${ }^{17}$ Early CVD of diamond was carried out by thermal decomposition of carbon-containing gases such as $\mathrm{CH}_{4}$ and $\mathrm{CO}^{18,19}$ at gas temperatures between 600 and $1200{ }^{\circ} \mathrm{C}$. The typical deposition conditions were: methane concentration of $1 \%$ in hydrogen, substrate temperature of $700-1000^{\circ} \mathrm{C}$, filament temperature approximately of $2000{ }^{\circ} \mathrm{C}$, total gas pressure of 13-133 mbar, and reaction time of $3 \mathrm{~h}$. The diamond growth rates are in the order of 0.1 to near $1000 \mathrm{~mm} \mathrm{~h}^{-1},{ }^{20}$ demonstrating the good prospect of diamond films for some industrial applications. The conductivity of diamond can be improved significantly by doping with boron. Boron doping is usually achieved by adding $\mathrm{B}_{2} \mathrm{H}_{6},{ }^{21,22}$ or $\mathrm{B}\left(\mathrm{OCH}_{3}\right)_{3}^{23,24}$ to the gas stream, or placing boron powder near the edges of the substrate prior to insertion into the CVD chamber. ${ }^{25}$ Since the late 70's and early 80's when CVD was established as an economical, relatively fast and easy process for producing diamond and it has been considered in different reviews and articles. ${ }^{26-28}$

\section{Electrochemistry of Diamond}

The first paper on the electrochemistry of boron doped polycrystalline diamond was published by Pleskov et al. in 1987. ${ }^{1}$ The demonstration of the possibility of performing electrochemistry on polycrystalline diamond resulted in considerable interest in electrodes fabricated from this new material. Three advantages of diamond electrodes were identified. First, it was demonstrated that diamond electrodes have a large potential window in aqueous solution with low background currents. ${ }^{29-59}$ Second, it was shown that electrodes formed from polycrystalline diamond possess physical properties similar to those of bulk diamond, ${ }^{60-64}$ including: hardness, low environmental impact, high hole mobility, high thermal conductivity and excellent resistance to radiation damage. Third, the surface is stable and there is little evidence of degradation of electrochemical activity with time to,43,65 $^{4}$ These characteristics of diamond electrodes have been employed in a number of applications.

The quality of conducting diamond films is usually investigated by recording the background cyclic voltammetric $j$ - $E$ curves of the electrodes. In fact, the magnitude of the background current, the working potential window and the features of the curves are sensitive to the presence of non-diamond carbon impurities. ${ }^{66-68}$ In general, high quality diamond film has a flat, featureless voltammetric response in the potential range between -0.3 and $1.2 \mathrm{~V}$ vs. SHE, with a background current 10 times lower than polished glassy carbon. ${ }^{7,51,69}$ Non-diamond surface impurities are more active than diamond and cause a higher background current. The increased surface charge density is evident from a larger double-layer charging current. ${ }^{69}$ Acidic washing, oxygen plasma and other techniques will oxidize the $\mathrm{sp}^{2}$ carbon and eliminate impurities from the 
diamond surface without any change in morphology or damage to the microstructure. Cyclic voltammetry can detect $\mathrm{sp}^{2}$ impurities and their removal with a higher sensitivity than Raman Spectroscopy. ${ }^{69}$

Another important property of high-quality diamond is the wide potential window between hydrogen and oxygen evolution. A total region of around four volts is available within which rather low background currents are recorded. ${ }^{29-33}$ With its combination of a low background current, an extremely high overvoltage for oxygen and hydrogen evolution, and an extremely high stability, diamond is a suitable material for some industrial applications.

Three classes of electrochemical applications may be identified: i) Synthesis of chemicals; ii) Electroanalysis and iii) Destruction of pollutants. The diamond surface is not favorable for adsorption, so that electrochemical processes that involve adsorbed intermediates $\left(\mathrm{H}_{2}, \mathrm{O}_{2}\right.$ and $\mathrm{X}_{2}$ evolution $)$ are hindered on diamond. They will require very high overpotential in order to proceed at an appreciable rate. The wide potential window without electrolyte decomposition and the high stability of diamond allow electrochemical reactions to be carried out at potentials otherwise difficult to reach. Direct synthetic reactions have been carried out, such as the production of ammonia, chlorine, $\mathrm{Ag}^{2+}$ and peroxodisulfate. ${ }^{70-74}$ Diamond has been tested in the oxidation of many organic compounds for wastewater treatment, and an extremely high current efficiency was obtained. ${ }^{75-78}$ The low background currents on diamond lead to an improved signal-to background ratio as compared with glassy carbon. ${ }^{79,80}$ Negligible adsorption phenomena have been found on diamond surfaces for a wide range of compounds. ${ }^{51}$ After partial surface fouling, the response of electrodes could be restored by simple electrochemical oxidation without modifying the morphological properties of the polycrystalline film. ${ }^{76,78}$

\subsection{Inner sphere reactions at diamond electrodes}

The BDD electrodes are characterized by very slow kinetics of inner-sphere reactions such as $\mathrm{O}_{2}$ evolution. In fact, very high overpotentials are required for these kind of processes. The very weak bond between the diamond surface and active intermediates (hydroxyl radicals) is the cause of the slow kinetics of this kind of a reaction. However, the weakly bonded hydroxyl radicals are chemically extremely active, and at potentials close to oxygen evolution, the oxidation of organics results in a complete combustion incineration of the organic species. In this potential region, all fouling effects are avoided and a very high current efficiency is obtained.

\subsection{The oxygen evolution reaction and organic oxidation} on 'non-active' and 'active' electrodes ${ }^{81}$

It has been found that, frequently, electrochemical oxidation of certain organics in aqueous media occurs, without any loss of electrochemical activity, only at high potential values, with concomitant evolution of oxygen. ${ }^{3,9,10,12,82}$ Furthermore, it has been found that the nature of the electrode material strongly influences both the selectivity and the efficiency of the process. ${ }^{13,14,83,84} \mathrm{In}$ order to interpret these observations, a comprehensive model has been proposed. ${ }^{13,14,83,84}$ This model allows two different cases to be distinguished: 'non-active' and 'active' anodes. The first step in all cases is the discharge of water molecules to hydroxyl radicals:

$\mathrm{M}+\mathrm{H}_{2} \mathrm{O} \rightarrow \mathrm{M}\left({ }^{\circ} \mathrm{OH}\right)+\mathrm{H}^{+}+e^{-}$

Where $\mathrm{M}$ designates an active site at the anode surface.

The electrochemical and chemical activity of hydroxyl radicals strongly depends on the nature of the electrode material used. With 'non-active' electrodes there is a weak interaction between electrode $M$ and hydroxyl radicals $(\cdot \mathrm{OH})$. In this case the oxidation of organics is controlled by hydroxyl radicals:

$M\left({ }^{\circ} \mathrm{OH}\right)+\mathrm{R} \rightarrow \mathrm{M}+m \mathrm{CO}_{2}+n \mathrm{H}_{2} \mathrm{O}+\mathrm{H}^{+}+e^{-}$

This reaction occurs in competition with oxygen evolution by hydroxyl radical discharge, which occurs without any participation of the anode surface:

$M(\cdot \mathrm{OH}) \rightarrow M+\frac{1}{2} \mathrm{O}_{2}+H^{+}+e^{-}$

With 'active' electrodes there is a strong interaction between electrode $\mathrm{M}$ and hydroxyl radicals ( $\mathrm{OH})$. In this case the hydroxyl radicals may interact with the anode, with a possible transfer of oxygen from the hydroxyl radicals to the anode surface and the formation of so-called higher oxide (reaction 4 with $\mathrm{M}=\mathrm{IrO}_{2}$ ).

$M\left({ }^{\circ} \mathrm{OH}\right) \rightarrow \mathrm{MO}+\mathrm{H}^{+}+e^{-}$

The surface redox couple MO/M can act as a mediator in the partial (selective) oxidation of organics (reaction 5 with $\mathrm{M}=\mathrm{IrO}_{2}$ ).

$M O+R \rightarrow M+R O$

This reaction occurs in competition with oxygen evolution due to chemical decomposition of the higher oxide (reaction 6 with $\mathrm{M}=\mathrm{IrO}_{2}$ ). 
$M O \rightarrow \frac{1}{2} O_{2}$

3.3. The oxygen evolution reaction and the oxidation of organic substances on 'non-active' diamond electrodes

Diamond electrodes have been defined as "nonactive' electrodes. In fact, they do not provide any catalytically active site for the adsorption of reactants and/or products in aqueous media. Intermediates such as hydroxyl radicals produced by water decomposition at 'non-active' anodes (reaction 1) are considered to be involved in the oxidation of organics in aqueous media. These intermediates are responsible for the electrochemical combustion of the organic compounds (reaction 5). The electrochemical activity (overpotential for oxygen evolution) and the chemical reactivity of adsorbed hydroxyl radicals (rate of oxidation of the organic substances by electrogenerated hydroxyl radicals) are strongly related to the strength of interaction between anode (M) and hydroxyl radicals $\left({ }^{\circ} \mathrm{OH}\right)$. As a general rule, the weaker the $\mathrm{M}-\mathrm{OH}^{\cdot}$ interaction, the lower will be the anode's activity toward oxygen evolution (high overvoltage anodes), and the higher its reactivity for the oxidation of organics (fast chemical reaction). At high anodic potentials close to the potential of water decomposition, the activity of BDD electrodes is considerably enhanced, and there is no evidence of a loss of electrode activity. ${ }^{71,75,76,78,85}$ In the case of aromatic compounds, it has been found that the polymeric film formed in the region of water stability can be destroyed by subjecting the electrode to high anodic potentials ( $>2.3 \mathrm{~V} v s$. SHE) in the region of $\mathrm{O}_{2}$ evolution. This treatment can restore the electrode's activity. In fact, the applied potential is located in the region of water discharge at BDD electrodes, and this involves the production of reactive intermediates (hydroxyl radicals, $\mathrm{OH}^{*}$ ) which oxidize the polymeric film on the anode surface.

A model has been developed ${ }^{13,14,77,83,84}$ to describe the combustion of organics (R) on BDD anodes. It assumes that both the oxidation of organics and the oxygen evolution reaction take place exclusively through mediation by hydroxyl radicals, i.e. the electrode itself does not exhibit any 'active' character. This assumption simplifies the general mechanism presented above according to reactions 1 to 6 , so that a reaction scheme involving three different reactions is obtained with $\mathrm{M}=\mathrm{BDD}$.

The first reaction is the electrochemical discharge of water leading to hydroxyl radical formation (reaction 1).

$B D D+\mathrm{H}_{2} \mathrm{O} \rightarrow B D D\left({ }^{\circ} \mathrm{OH}\right)+H^{+}+e^{-}$
These hydroxyl radicals are then consumed by two competing reactions: $i$ ) combustion of organics (reaction 2):

$\mathrm{BDD}\left({ }^{\circ} \mathrm{OH}\right)+\mathrm{R} \rightarrow \mathrm{BDD}+m \mathrm{CO}_{2}+n \mathrm{H}_{2} \mathrm{O}+\mathrm{H}^{+}+e^{-}$

and ii) oxygen evolution (reaction 3):

$B D D\left({ }^{\circ} \mathrm{OH}\right) \rightarrow B D D+\frac{1}{2} \mathrm{O}_{2}+H^{+}+e^{-}$

Molecular oxygen very probably also participates in the combustion of organics according to the following reaction scheme:

1) Formation of organic radicals, $R^{*}$, by a dehydrogenation mechanism:

$\mathrm{RH}+\mathrm{BDD}\left({ }^{*} \mathrm{OH}\right) \rightarrow \mathrm{R}^{*}+\mathrm{H}_{2} \mathrm{O}+\mathrm{BDD}$

2) Reaction of the organic radical with dioxygen

$\mathrm{R}^{*}+\mathrm{O}_{2} \rightarrow \mathrm{ROO}^{*}$

3) Further abstraction of a hydrogen atom with the formation of an organic hydroperoxide $(\mathrm{ROOH})$ :

$\mathrm{ROO}^{*}+\mathrm{R}^{\prime} H \rightarrow \mathrm{ROOH}+\mathrm{R}^{\prime *}$

Since the organic hydroperoxides are relatively unstable, decomposition of such intermediates often leads to molecular breakdown and formation of subsequent intermediates with lower carbon numbers. These scission reactions continue rapidly until the organic substance has been completely transformed to $\mathrm{CO}_{2}$ and $\mathrm{H}_{2} \mathrm{O}$. A kinetic model can be developed for this reaction scheme by making the following further assumptions: $i$ ) adsorption of the organic compounds at the electrode surface is negligible; ii) the overall rate of electrochemical combustion of organics (involving hydroxyl radicals and the formation of hydroperoxide) is a fast reaction and is controlled by mass transport of organics to the anode surface.

\section{BDD Electrode for Wastewater Treatment}

The boron-doped diamond film electrode represents an attractive anode material for the degradation of refractory or priority pollutants such as ammonia, cyanide, phenol, chlorophenols, aniline, various dyes, surfactants, alcohols and many other compounds. ${ }^{16,86-121}$ Unlike $\mathrm{PbO}_{2}, \mathrm{SnO}_{2}$ and $\mathrm{TiO}_{2}$, the BDD thin films deposited on $\mathrm{Si}, \mathrm{Ta}, \mathrm{Nb}$ and $\mathrm{W}$ by CVD have shown excellent electrochemical stability. ${ }^{24}$ However, the application of BDD electrodes for wastewater 
treatment has been mostly studied with Si-supported devices, in spite of the difficulties related to their industrial application, due to the fragility and the relatively low conductivity of the Si substrate. On the other hand, largescale usage of $\mathrm{Nb} / \mathrm{BDD}, \mathrm{Ta} / \mathrm{BDD}$ and $\mathrm{W} / \mathrm{BDD}$ electrodes is impossible due to the unacceptably high costs of $\mathrm{Nb}, \mathrm{Ta}$ and $\mathrm{W}$ substrates. On the contrary, titanium possesses all required features to be a good substrate material; Ti/BDD has been used for the destruction of several pollutants, like dyes, ${ }^{122,123}$ carboxylic acids ${ }^{123}$ and phenol. ${ }^{123}$ Carey et al. patented the use of diamond films as anodes for organic pollutants oxidation. ${ }^{104}$ Also Comninellis and coworkers investigated the anodic oxidation of various pollutants with $\mathrm{Si} / \mathrm{BDD}$ electrodes, as well as the mechanism by which the organic substrates are oxidized at this electrode surface through the formation of a film of hydroxyl radicals at the $\mathrm{Si} / \mathrm{BDD}$ surface, which may represent a 'reaction cage' for the process. . $^{24,75,76,85,92,96-100,103,106,120}$ Related results have been summarized in Table 1. The CE obtained is very high, ranging from 33.4 to more than $95 \%$, depending on pollutant characteristics and oxidation conditions. The work by Beck et al. ${ }^{124}$ also reports results obtained by Fryda et al. ${ }^{24}$, comparing the $\mathrm{Si} / \mathrm{BDD}$ with $\mathrm{Ti} / \mathrm{SnO}_{2}, \mathrm{Ta} / \mathrm{PbO}_{2}$ and $\mathrm{Pt}$ for the oxidation of phenol. At a charge loading of $20 \mathrm{Ah} \mathrm{L}^{-1}$, the total organic carbon (TOC) was reduced from an initial value of 1500 to about $50 \mathrm{mg} \mathrm{L}^{-1}$ at $\mathrm{Si} / \mathrm{BDD}$, and to about 300, 650 and $950 \mathrm{mg} \mathrm{L}^{-1}$ at $\mathrm{Ti} / \mathrm{SnO}_{2}, \mathrm{Ta} / \mathrm{PbO}_{2}$ and $\mathrm{Pt}$, respectively.

On the other hand, some articles report that during oxidation of organic compounds, such as phenol, diuron, 3,4-dichloroaniline and triazines, the crucial point to obtain high yields is the rate of mass transfer of the reactant towards the electrode surface. ${ }^{93-95}$ Thus, they developed an impinging cell to obtain high mass transfer coefficients. With this cell, at a current density of $15 \mathrm{~mA} \mathrm{~cm}{ }^{-2}$, a faradic yield of $100 \%$ was achieved, up to the almost complete disappearance of the organic load. ${ }^{93-95}$

Some papers have also compared the behavior of $\mathrm{BDD}$ with other electrodes, such as $\mathrm{SnO}_{2}, \mathrm{PbO}_{2}, \mathrm{IrO}_{2}$, for the oxidation of organic pollutants. Chen et al. reported that the current efficiency obtained with Ti/BDD in oxidizing acetic acid, maleic acid, phenol, and dyes was 1.6-4.3-times higher than that obtained with the typical $\mathrm{Ti} / \mathrm{Sb}_{2} \mathrm{O}_{5}-\mathrm{SnO}_{2}$ electrode. ${ }^{123}$ Other have demonstrated that $\mathrm{Si} / \mathrm{BDD}$ electrodes are able to achieve faster oxidation and better incineration efficiency than $\mathrm{PbO}_{2}$ in the treatment of naphthol, ${ }^{107,108}$ 4-chlorophenol ${ }^{85}$ and chloranilic acid. ${ }^{88}$ In contrast, the incineration of oxalic acids, ${ }^{86}$ which require a strong adsorption of the organic on the electrode surface, is lower than on $\mathrm{PbO}_{2}$, but is higher than on $\mathrm{Pt}, \mathrm{Au}$ and $\mathrm{IrO}_{2}$ anodes.
The diamond electrodes have been also used as cathode materials for the electrochemical reduction of nitrate ions dissolved in high concentrations in effluents. ${ }^{125-128}$. LevyClement et al. ${ }^{126}$ found that at applied potentials between -1.5 and $-1.7 \mathrm{~V}$ vs. SCE the amount of $\mathrm{NO}_{3}^{-}$reduced is a constant $10 \%$ and that it is mainly transformed into gaseous products, then it increases to $29 \%$ at $-2 \mathrm{~V}$ with almost equal parts of nitrite and nitrogenous gas formed, without the production of ammonium.

Another aspect to be taken into consideration is the production of powerful oxidants, like the peroxodisulphate, ${ }^{129,130}$ these species can participate in the oxidation of the organic substrates, allowing higher efficiencies.

In particular cases, for high organic concentrations and low current densities, the chemical oxygen demand (COD) decreased linearly and the Instantaneous Current Efficiency (ICE) remained about 100\%, indicating a kinetically controlled process. While for low organic concentrations or high current densities, the COD decreased exponentially and the ICE began to fall due to the mass-transport limitation and the side reactions of oxygen evolution. For example, the trend of the COD and ICE was obtained by Panizza et al. ${ }^{76}$ during the electrochemical oxidation of 2-naphthol. In order to describe these results these authors developed a comprehensive kinetic model that allowed them to predict the trend of the COD and current efficiency for the electrochemical combustion of the organic with BDD electrodes and to estimate the energy consumption during the process. ${ }^{76,77,110}$

Other applications of BDD for the destruction and/or determination of organic pollutants were obtained by Avaca and co-workers ${ }^{105,131-139}$ where the comparison between the BDD and other anodic materials have permitted use of alternative techniques during the oxidation of the organic pollutants. The BDD electrode is the best choice for several electroanalysis studies, as demonstrated by the electrochemical oxidation of 4nitrophenol in $0.1 \mathrm{~mol} \mathrm{~L}^{-1}$ BR buffer electrolyte. ${ }^{131}$

A comparison between the analysis performance of a hanging mercury drop electrode (HMDE) and a BDD electrode for the quantification of 4-nitrophenol (4-NP) in spiked pure and natural waters was reported. ${ }^{132}$ The square wave voltammetry was chosen as the electroanalysis technique. For the reduction process, the quantification limits varied between 5.7 and $66.0 \mu \mathrm{g} \mathrm{L}^{-1}$ for the HMDE and between 14.1 and $61.3 \mu \mathrm{g} \mathrm{L}^{-1}$ for the BDD electrode for water samples with increasing degree of contamination. The oxidation of 4-NP on BDD was also used for analysis purposes and the quantification limits in this case varied from 9.4 to $53.1 \mu \mathrm{g} \mathrm{L}^{-1}$. Also this material was used for determining 


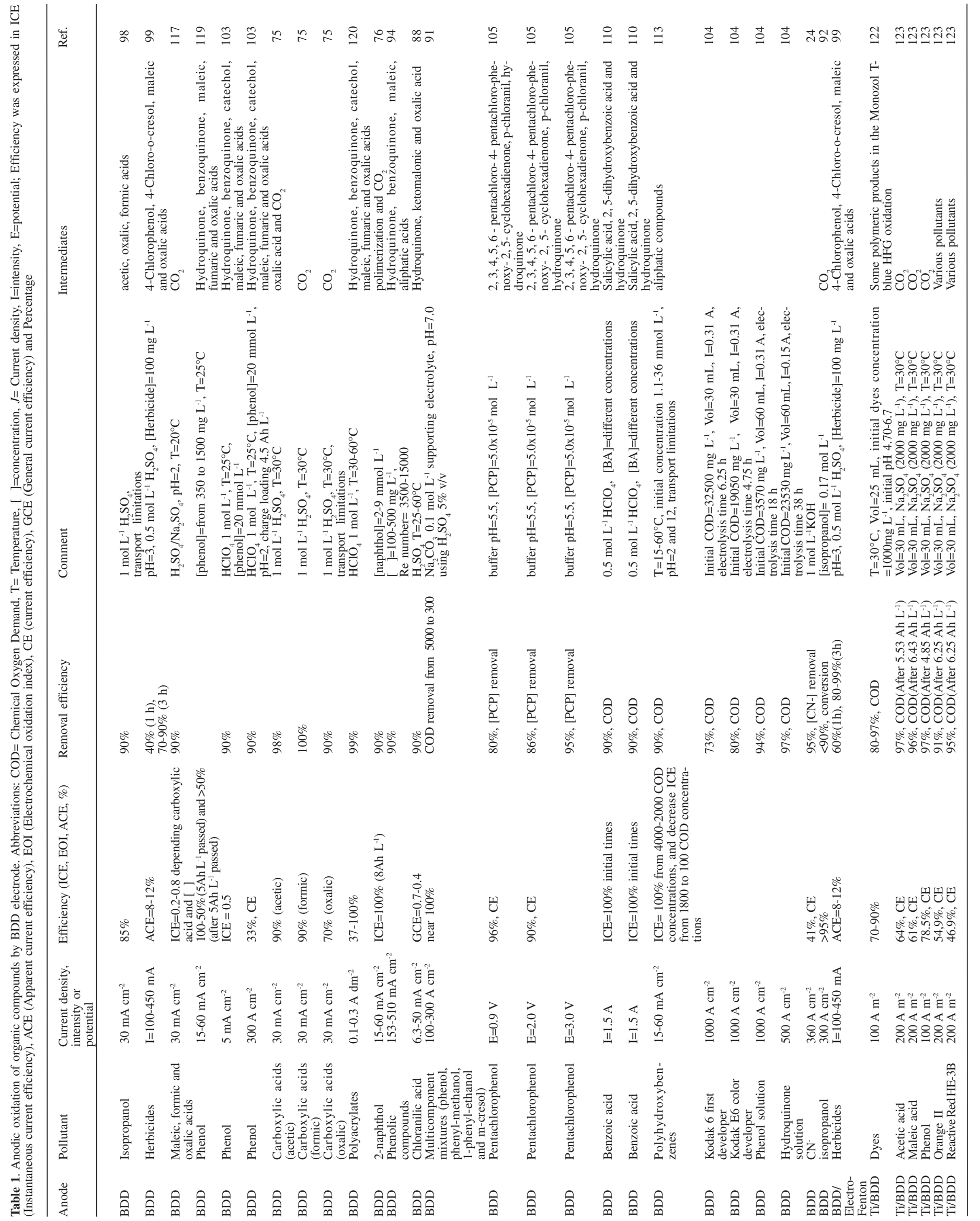


the pentachlorophenol in waters and these results were satisfactorily compared with those obtained on a conventional $\mathrm{Hg}$ electrode showing that the use of the BDD electrode is an interesting and desirable alternative for analytical detections. These latter results illustrate the advantages arising from the possibility of using an oxidation process on BDD electrodes for analytical purposes in contaminated matrixes.

Also the column of intermediates is a key point for the evaluation of data in Table 1: in fact, several metabolites are generally produced during the oxidation of the original organic substrate. Starting from an aromatic compound, hydroxylated derivatives are found as initial intermediates, but in the final stages of the oxidation process several carboxylic acids are produced, the last being usually oxalic acid. The formation of these acids increases the process time and highlights possible mass transport limitations; interestingly, some anode materials are more efficient than others for their elimination. ${ }^{86}$

\section{Final Remarks}

This paper has attempted to give an overview of the applications of BDD electrode in the wastewater treatment and the mechanisms during this process. Without doubt the BDD electrodes have showed numerous applications in the electrochemistry area of research. The most important properties of this electrode are a large potential window, lower adsorption, corrosion stability in very aggressive media, high efficiency in oxidation processes, very low double-layer capacitance and background current. All of these characteristics make this material ideal in the elimination of organics from water. Also, thanks to these properties, conducting diamond seems to be a promising electrode material and so, in the last decades, it has been studied with the goal of developing applications in three broad areas: electro-synthesis, electro-analysis and sensor technology; and water treatment, which includes the purification of wastewater and the disinfection of drinking water.

Due to the importance of BDD in the electrochemistry research; the number of articles about production and applications of this material have increased in various countries. Also other recent and relevant papers in this field have been published during this year. ${ }^{140-144}$

\section{Special Dedication}

Dedicated to Professor Christos Comninellis for the experimental and scientific contributions about the wastewater treatment using the Boron-Doped Diamond electrode, as well as for his articles about the electrochemical oxidation of the organic pollutants.

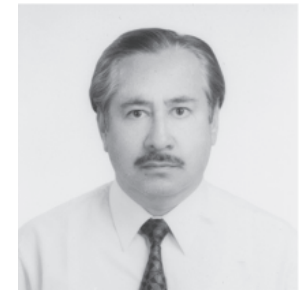

Marco A. Quiroz Alfaro was born in Puebla, México; he obtained his B.S. in Chemistry (1977) at the Universidad Autónoma de Puebla; his Master in Chemistry (1979) and Ph.D. degree in Science (1985) at the Universidad Autónoma Metropolitana. In 1982 he moved to France as visiting scientist under a collaborative scientific program with the University of Poitiers. He was full professor at the UAM-Chemistry Department from 1976 until 1989. Since 1989 he is full time professor and researcher at the Universidad de las Américas - Puebla.. Author of about 43 scientific publications, one patented and more than 100 scientific contributions in national and international congresses.

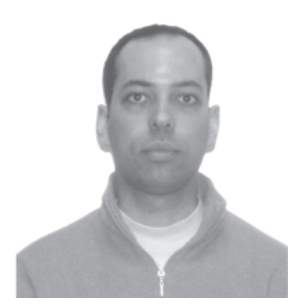

Sergio Ferro was born in 1972; he got his

"Laurea" in Chemistry in 1997, and earned a PhD in Chemical Sciences at the University of Ferrara in 2001, where he's now working as a research assistant. Author of about 30 papers on international journals, co-author of 2 book's chapters and 3 patents, he was awarded by national and international scientific committees. His work deals mostly with electrocatalysis, regarded as an extension of the heterogeneous catalysis, of its principles and methods, to electrochemical reactions.

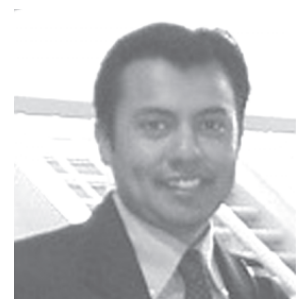

Carlos A. Martinez-Huitle was born in Mexico City, in 1977. He graduated in chemistry at the Universidad de las Américas - Puebla (2000). After a work experience in Ciba - Specialty Chemicals, he moved to the University of Ferrara, Italy (2002), to work under the supervision of Prof. Achille De Battisti. Here, he earned a PhD in chemical science (2005). During the same period, he worked as visiting scientist in the group of Prof. Christos Comninellis at the EPFL Institute, Switzerland. Actually, he is a faculty member at the University of Milan. His research interests include electrochemical oxidation, electrocatalysis and electroanalysis.

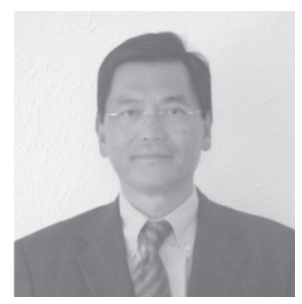

Dr. Yunny Meas Vong is head of the Department of Electrochemistry, Center of Research and Technological Development in Electrochemistry (CIDETEQ). He received his $P h D$ in Electrochemistry and his electrochemical engineer degree from Institut National Polytechnique de Grenoble (France). His research focuses on electrochemical deposition processes, as well as corrosion inhibitors and electrochemical waste water treatment processes. 


\section{References}

1. Pleskov, Y. V.; Krotova, M. D.; Bouilov, L. L.; Spitsyn, B. P.; J. Electroanal. Chem. 1987, 19, 228

2. Perret, A.; Haenni, W.; Niedermann, P.; Skinner, N.; Comninellis, Ch.; Gandini, D.; Proc. - Electrochem. Soc. 1998, 97, 275.

3. Swain, G. M.; Ramesham, R.; Anal. Chem. 1993, 65, 345.

4. Yang, S.; Zhu, J.; Yao, Y.; Zhang, X.; International Conference on New Diamond Science and Technology, $4^{\text {th }}$ ed., Kobe, Japan, 1994, p.741.

5. Higson, S. P. J.; Vadgama, P. M.; Anal. Chim. Acta 1992, 271, 125.

6. Zhang, X. K.; Zhu, J. Z.; Wang, R.; Liu, X. H.; Yao, Y. F.; Wu, J. L.; Mat. Lett. 1994, 18, 318.

7. Duo, I.; Michaud, P. A.; Haenni, W.; Perret, A.; Comninellis, Ch.; Electrochem. Solid-State Lett. 2000, 3, 325.

8. Duo, I.; Comninellis, C.; Haenni, W.; Perret, A.; Proc. Electrochem. Soc. 2001, 25, 147.

9. Comninellis, Ch.; Plattner, E.; Chimia 1988, 42, 250.

10. Comninellis, Ch.; Pulgarin, C.; J. Appl. Electrochem. 1991, 21,703 .

11. Comninellis, Ch.; Gas Wasser, Abwasser. 1992, 11, 792.

12. Comninellis, Ch.; Pulgarin, C.; J. Appl. Electrochem. 1993, 23,108 .

13. Comninellis, Ch.; De Battisti, A.; J. Chim. Phys. 1996, 93, 673.

14. Comninellis, Ch.; Electrochim. Acta 1994, 39, 1857.

15. Foti, G.; Gandini, D.; Comninellis, Ch.; Current Topics in Electrochemistry 1997, 5, 71.

16. Marselli, B.; Garcia-Gomez, J.; Michaud, P.-A.; Rodrigo, M. A.; Comninellis, Ch.; J. Electrochem. Soc. 2003, 150, D79.

17. Asmussen, J.; Reinhard, D.K.; Diamond Film Handbook, Michigan State University: East Lansing, MI, 2002.

18. Eversole, W.G.; Synthesis of Diamond, US Patents 3,030,187; 3,030,188 1962

19. Angus, J.C.; Will, H.A.; Stanko, W.S.; J. Appl. Phys. 1968, 39, 2915.

20. Bachmann, P.K. In Thin Film Diamond, Lettington, A.; Steeds, J.W., eds., Chapman \& Hall: London, 1994, p.31.

21. Mort, J.; Kuhman, D.; Machonkin, M.; Morgan, M.; Jansen, F.; Okumura, K.; Legrice, Y.M.; Nemanich, R.J.; Appl. Phys. Lett. 1989, 55, 1121.

22. Fujimori, N.; Nakahata, H.; Imai, T.; Jpn. J. Appl. Phys. 1990, 29, 824.

23. Ran, J.G.; Zheng, C.Q.; Ren, J.; Hong, S.M.; Diamond Relat. Mater. 1993, 2, 793.

24. Fryda, M.; Herrmann, D.; Schafer, L.; Klages, C.P.; Perret, A.; Haenni, W.; Comninellis, Ch.; Gandini, D.; New Diamond Front. Carbon Technol. 1999, 9, 229.

25. Grot, S.A.; Gildenblat, G.S.; Hatfield, C.W.; Wronski, C.R.; Badzian, A.R.; Badzian, T.; Messier, R.; IEEE Electron Device Lett. 1990, 11, 100 .
26. Ferro, S.; J. Math. Chem. 2002, 12, 2843.

27. Angus, J. C.; Martin, H. B.; Landau, U.; Evstefeeva, Y. E.; Miller, B.; Vinokur, N.; New Diamond Front. Carbon Technol. 1999, 9, 175

28. Fujishima, A.; Terashima, C.;. Honda, K; Sarada, B. V.; Rao, T. N.; New Diamond Front. Carbon Technol. 2002, 12, 73.

29. Spataru, N.; Rao, T. N.; Tryk, D. A.; Fujishima, A.; J. Electrochem. Soc. 2001, 148, E112.

30. Spataru, N.; Sarada, B. V.; Popa, E.; Tryk, D. A.; Fujishima, A.; Anal. Chem. 2001, 73, 514.

31. Uchikado, R.; Rao, T. N.; Tryk, D. A.; Fujishima, A.; Chem. Lett. 2001, 144.

32. Ohnishi, K.; Einaga, Y.; Notsu, H.; Terashima, C.; Rao, T. N.; Park, S. G.; Fujishima, A.; Electrochem. Solid-State Lett. 2002, 5, D1.

33. Prado, C.; Flechsig, G. U.; Grundler, P.; Foord, J. S.; Marken, F.; Compton, R. G.; Analyst 2002, 127, 329.

34. Compton, R. G.; Marken, F.; Goeting, C. H.; McKeown, R. A. J.; Foord, J. S.; Scarsbrook, G.; Sussman, R. S.; Whitehead, A. J.; Chem. Commun. 1998, 1961.

35. Goeting, C.H.; Marken, F.; Compton, R. G.; Foord, J. S.; Chem. Сотmun. 1999, 17, 1697.

36. Goeting, C. H.; Foord, J.S.; Marken, F.; Compton, R.G.; Diamond Relat. Chem. 1999, 8, 824.

37. Saterlay, A. J.; Wilkins, S. J.; Goeting, C. H.; Foord, J. S.; Compton R. G.; Marken, F.; J. Solid State Electrochem. 2000, 4, 383.

38. Saterlay, A. J.; Marken, F.; Foord, J. S.; Compton, R. G.; Talanta 2000, 53, 403.

39. Foord, J.S.; Holt, K.B.; Compton, R.G.; Marken, F.; Kim, D.H.; Diamond Relat. Chem. 2001, 10, 662.

40. Holt, K.B.; Del Campo, J.; Foord, J. S.; Compton, R. G.; Marken, F.; J. Electroanal. Chem. 2001, 513, 94.

41. Saterlay, A. J.; Wilkins, S. J.; Holt, K. B.; Foord, J. S.; Compton, R. G.; Marken, F.; J. Electrochem. Soc. 2001, 148, E66.

42. Wadhawan, J. D.; Del Campo, F. J.; Compton, R. G.; Foord, J. S.; Marken, F.; Bull, S. D.; Davies, S. G.; Walton, D. J.; Ryley, S.; J. Electroanal. Chem. 2001, 507, 135.

43. Terashima, C.; Rao, T. N.; Sarada, B. V.; Tryk, D. A.; Fujishima, A.; Anal. Chem. 2002, 74, 895.

44. Prado, C.; Wilkins, S. J.; Marken, F.; Compton, R. G.; Electroanalysis 2002, 14, 262.

45. Witek, M. A.; Swain, G. M., Abstr. Pap. Am. Chem. Soc. 2001, 222, 59.

46. Tryk, D.A.; Tsunozaki, K.; Rao, T. N.; Fujishima, A.; Diamond Relat. Chem. 2001, 10, 1804.

47. Tsai, Y.C.; Coles, B.A.; Holt, K.; Foord, J.S.; Marken, F.; Compton, R.G.; Electroanalysis 2001, 13, 831.

48. Notsu, H.; Fukazawa, T.; Tatsuma, T.; Tryk, D. A.; Fujishima, A.; Electrochem. Solid-State Lett. 2001, 4, H1.

49. Chailapakul, O.; Aksharanandana, P.; Frelink, T.; Einaga, Y.; Fujishima, A.; Sens. Actuators, B 2001, 80, 193. 
50. Rao, T. N.; Sarada, B. V.; Tryk, D. A.; Fujishima, A.; J. Electroanal. Chem. 2000, 491, 175.

51. Rao, T. N.; Fujishima, A.; Diamond Relat. Chem. 2000, 9, 384.

52. Kuo, T.; McCreery, R. L.; Swain, G. M.; Electrochem. SolidState Lett. 1999, 2, 288.

53. Koppang, M. D.; Witek, M.; Blau, J.; Swain, G. M.; Anal. Chem. 1999, 71, 1188.

54. Wu, Z. Y.; Yano, T.; Tryk, D. A.; Hashimoto, K.; Fujishima, A.; Chem. Lett. 1998, 503.

55. Yano, T.; Tryk, D. A.; Hashimoto, K.; Fujishima, A.; J. Electrochem. Soc. 1998, 145, 1870.

56. DeClements, R.; Swain, G. M.; J. Electrochem. Soc. 1997, 144, 856.

57. Strojek, J. W.; Granger, M. C.; Swain, G. M.; Dallas, T.; Holtz, M. W.; Anal. Chem. 1996, 68, 2031.

58. Alehashem, S.; Chambers, F.; Strojek, J. W.; Swain, G. M.; Ramesham, R.; Anal. Chem. 1995, 67, 2812.

59. Swain, G.; Adv. Mater. 1994, 6, 388.

60. Angus, J. C.; Hayman, C. C.; Science 1988, 241, 913.

61. Bachmann, P. K.; Messier, R.; Chem. Eng. News 1989, 67, 24.

62. Geis, M. W.; Angus, J. C.; Sci. Am. 1992, 267, 84.

63. Geis, M. W.; Angus, J. C.; Sci. Am. 1994, 270, 10.

64. Ramesham, R.; Hill, D. C.; Best, S. R.; Rose, M. F.; Askew, R. F.; Thin Solid Films 1995, 257, 68.

65. Granger, M. C.; Xu, J. S.; Strojek, J. W.; Swain, G. M.; Anal. Chim. Acta 1999, 397, 145.

66. Pleskov, Y. V.; Russ. Chem. Rev. 1999, 68, 381.

67. Swain, G. M.; Anderson, A. B.; Angus, J. C.; MRS Bull. 1998, $23,56$.

68. Tenne, R.; Lévy-Clément, C. ; Isr. J. Chem. 1998, 38, 57.

69. Granger, M. C.; Witek, M.; Xu, J.; Wang, J.; Hupert, M.; Hanks, A.; Koppang, M. D.; Butler, J. E.; Lucazeau, G.; Mermoux, M.; Strojek, J. W.; Swain, G. M.; Anal. Chem. 2000, 72, 3793.

70. Ferro, S.; De Battisti, A.; Duo, I.; Comninellis, Ch.; Haenni, W.; Perret, A.; J. Electrochem. Soc. 2000, 147, 2614.

71. Iniesta, J.; Michaud, P.-A.; Panizza, M.; Comninellis, Ch.; Electrochem. Commun. 2001, 3, 346.

72. Reuben, C.; Galun, E.; Cohen, H.; Tenne, R.; Kalish, R.; Muraki, Y.; Hashimoto, K.; Fujishima, A.; Butler, J. M.; Lévy-Clément, C.; J. Electroanal. Chem. 1995, 396, 233.

73. Panizza, M.; Duo, I.; Michaud, P.-A.; Cerisola, G.; Comninellis, Ch.; Electrochem. Solid-State Lett. 2000, 3, 550.

74. Michaud, P.-A.; Comninellis, Ch.; Haenni, W.; Perret, A.; Fryda, M. In International Patent, 2001.

75. Gandini, D.; Mahé, E.; Michaud, P.-A.; Haenni, W.; Perret, A.; Comninellis, Ch.; J. Appl. Electrochem. 2000, 30, 1345.

76. Panizza, M.; Michaud, P.-A.; Cerisola, G.; Comninellis, Ch.; J. Electroanal. Chem. 2001, 507, 206.

77. Panizza, M.; Michaud, P.-A.; Cerisola, G.; Comninellis, Ch.; Electrochem Commun. 2001, 3, 336.
78. Rodrigo, M. A.; Michaud, P.-A.; Duo, I.; Panizza, M.; Cerisola, G.; Comninellis, Ch.; J. Electrochem. Soc. 2001, 148, D60.

79. Engstrom, R. C.; Strasser, V. A.; Anal. Chem. 1984, 56, 136.

80. Hu, I.-F.; Karweik, D. H.; Kuwana, T.; J. Electroanal. Chem. 1985, 188, 59.

81. Fóti, G.; Comninellis, Ch. In Modern Aspects of Electrochemistry; Conway, B.E; White, R.E.; Vayenas, C.G., eds., Plenum Press: New York, vol. 37, in press.

82. Comninellis, Ch.; Nerini, A.; J. Appl. Electrochem. 1995, 25, 23.

83. Simond, O.; Shaller, V.; Comninellis, Ch.; Electrochim. Acta 1997, 42, 2009.

84. Fóti, G.; Gandini, D.; Comninellis, Ch.; Perret, A.; Haenni, W.; Electrochem. Solid-State Lett. 1999, 2, 228.

85. Gherardini, L.; Michaud, P.-A.; Panizza, M.; Comninellis, Ch.; Vatistas, N.; J. Electrochem. Soc. 2001, 148, D78.

86. Martínez-Huitle, C. A.; Ferro, S.; De Battisti, A.; Electrochim. Acta 2004, 49, 4027.

87. Michaud, P.A.; Thesis No. 2595, EPFL, Switzerland, 2002.

88. Martínez-Huitle, C.A.; Quiroz, M.A.; Comninellis, Ch.; Ferro, S.; De Battisti, A.; Electrochim. Acta 2004, 50, 949.

89. Martínez-Huitle, C.A.; Ferro, S.; De Battisti, A.; J. Appl. Electrochem. 2005, 35, 1087.

90. Kraft, A.; Stadelmann, M.; Blaschke, M.; J. Hazard. Mater. 2003, 103, 247.

91. Morao, A.; Lopes, A.; Amorim, M.T.P.d.; Gonçalves, I.C.; Electrochim. Acta 2004, 49, 1587.

92. Perret, A.; Haenni, W.; Skinner, N.; Tang, X.M.; Gandini, D.; Comninellis, Ch.; Correa, B.; Foti, G.; Diamond Relat. Mater. 1999, 8,820 .

93. Polcaro, A.M.; Vacca, A.; Mascia, M.; Palmas, S.; Electrochim. Acta 2005, 50, 1841.

94. Polcaro, A.M.; Vacca, A.; Palmas, S; Mascia, M.; J. Appl. Electrochem. 2003, 33, 885.

95. Polcaro, A.M.; Mascia, M.; Palmas, S.; Vacca, A.; Electrochim. Acta 2004, 49, 649.

96. Boye, B.; Michaud, P.A.; Marselli, B.; Dieng, M.M.; Brillas, E.; Comninellis, Ch.; New Diamond Front. Carbon Technol. 2002, 12, 63 .

97. Gandini, D.; Comninellis, Ch.; Perret, A.; Haenni, W.; ICHEME Symp. Ser. 1999, 145, 181.

98. Gandini, D.; Michaud, P.A.; Duo, I.; Mahe, E.; Haenni, W.; Perret, A.; Comninellis, Ch.; New Diamond Front. Carbon Technol. 1999, 9, 303.

99. Brillas, E.; Boye, B.; Sires, I.; Garrido, J.A.; Rodriguez, R.M.; Arias, C.; Cabot, P.L.; Comninellis, Ch.; Electrochim. Acta 2004, 49, 4487.

100. Montilla, F.; Michaud, P.A.; Morallon, E.; Vazquez, J.L.; Comninellis, Ch.; Electrochim. Acta 2002, 47, 3509.

101. Lissens, G.; Pieters, J.; Verhaege, M.; Pinoy, L.; Verstraete, W.; Electrochim. Acta 2003, 48, 1655. 
102. Troster, I.; Fryda, M.; Herrmann, D.; Schafer, L.; Haenni, W.; Perret, A.; Blaschke, M.; Kraft, A.; Stadelmann, M.; Diamond Relat. Mater. 2002, 11, 640.

103. Iniesta, J.; Michaud, P.A.; Panizza, M.; Cerisola, G.; Aldaz, A.; Comninellis, Ch.; Electrochim. Acta 2001, 46, 3573.

104. Carey, J.J.; Christ, J.C.S.; Lowery, S.N.; US Patent 5,399,247, 1995.

105. Codognoto, L.; Machado, S.A.S.; Avaca, L.A.; J. Appl. Electrochem. 2003, 33, 951.

106. Ouattara, L.; Duo, I.; Diaco, T.; Ivandini, A.; Honda, K.; Rao, T.N.; Fujishima, A.; Comninellis, Ch.; New Diamond Front. Carbon Technol. 2003, 13, 97.

107. Panizza, M.; Cerisola, G.; Electrochim. Acta 2003, 48, 3491.

108. Panizza, M.; Cerisola, G.; Electrochim. Acta 2004, 49, 3221.

109. Panizza, M.; Delucchi, M.; Cerisola, G.; J. Appl. Electrochem. 2005, 35, 357.

110. Rodrigo, M.A.; Michaud, P.A.; Duo, I.; Panizza, M.; Cerisola, G.; Comninellis, Ch.; J. Electrochem. Soc. 2001, 148, D60.

111. Canizares, P.; Saez, C.; Lobato, J.; Rodrigo, M.A.; Electrochim. Acta 2004, 49, 4641.

112. Canizares, P.; Saez, C.; Lobato, J.; Rodrigo, M.A.; Ind. Eng. Chem. Res. 2004, 43, 1944.

113. Canizares, P.; Saez, C.; Lobato, J.; Rodrigo, M.A.; Ind. Eng. Chem. Res. 2004, 43, 6629.

114. Canizares, P.; Martinez, F.; Diaz, M.; Garcia-Gomez, J.; Rodrigo, M.A.; J. Electrochem. Soc. 2002, 149, D118.

115. Canizares, P.; Garcia-Gomez, J.; Saez, C.; Rodrigo, M.A.; J. Appl. Electrochem. 2003, 33, 917.

116. Canizares, P.; Garcia-Gomez, J.; Saez, C.; Rodrigo, M.A.; J. Appl. Electrochem. 2004, 34, 87.

117. Canizares, P.; Garcia-Gomez, J.; Lobato, J.; Rodrigo, M.A.; Ind. Eng. Chem. Res. 2003, 42, 956.

118. Canizares, P.; Garcia-Gomez, J.; Lobato, J.; Rodrigo, M.A.; Ind. Eng. Chem. Res. 2004, 43, 1915.

119. Canizares, P.; Diaz, M.; Dominguez, J.A.; Garcia-Gomez, J.; Rodrigo, M.A.; Ind. Eng. Chem. Res. 2002, 41, 4187.

120. Bellagamba, R.; Michaud, P.A.; Comninellis, Ch.; Batistas, N.; Electrochem. Commun. 2002, 4, 171.

121. Hattori, S.; Dói, M.; Takahashi, E.; Kurosu, T.; Nara, M.; Nakamatsu, S.; Nishiki, Y.; Furuta, T.; Iida, M.; J. Appl. Electrochem. 2003, 33, 85.

122. Chen, X.; Chen, G.; Yue P. L.; Chem. Eng. Sci. 2003, 58, 995.

123. Chen, X.; Chen, G.; Gao, F.; Yue, P. L.; Environ. Sci. Technol. 2003, 37, 5021
124. Beck, F.; Kaiser, W.; Krohn, H.; Electrochim. Acta 2000, 45, 4691.

125. Bouamrane, F.; Tadjeddine, A.; Butler, J.E.; Tenne, R.; LevyClement, C.; J. Electroanal. Chem. 1996, 405, 95.

126. Levy-Clement, C.; Ndao, N.A.; Katty, A.; Bernard, M.; Deneuville, A.; Comninellis, Ch.; Fujishima, A; Diamond Relat. Mater. 2003, 12, 606.

127. Ndao, A.N.; Zenia, F.; Deneuville, A.; Bernard, M.; LevyClement, C.; Diamond Relat. Mater. 2000, 9, 1175.

128. Sine, G.; Ouattara, L.; Panizza, M.; Comninellis, Ch.; Electrochem. Solid-State Lett. 2003, 6, D9.

129. Michaud, P.-A.; Mahe, E.; Haenni, W.; Perret, A.; Comninellis, Ch.; Electrochem. Solid-State Lett. 2000, 3, 77.

130. Michaud, P.-A.; Comninellis, Ch.; Haenni, W.; Perret, A.; Fryda, M.; International Patent, WO 01/25508.

131. Pedrosa, V. A.; Suffredini, H. B.; Codognoto, L.; Tanimoto, S. T.; Machado, S. A. S.; Avaca, L. A.; Anal. Lett. 2005, 38, 1115.

132. Pedrosa, V. A.; Codognoto, L.; Machado, S. A. S.; Avaca, L. A.; J. Electroanal. Chem. 2004, 573, 11.

133. Suffredini, H. B.; Pedrosa, V. A.; Codognoto, L.; Machado, S. A. S.; Rocha-Filho, R. C.; Avaca, L. A.; Electrochim. Acta 2004, 49, 4021

134. Codognoto, L.; Zuin, V. G.; de Souza, D.; Yariwake, J. H.; Machado, S. A. S.; Avaca, L. A.; Microchem. J. 2004, 77, 177.

135. Suffredini, H. B.; Machado, S. A. S.; Avaca, L. A.; J. Braz. Chem. Soc. 2004, 15, 16.

136. Pedrosa, V. A.; Codognoto, L.; Avaca, L. A.; Quim. Nova 2003, 26, 844 .

137. Pedrosa, V.A.; Codognoto, L.; Avaca, L. A.; J. Braz. Chem. Soc. 2003, 14, 530.

138. Avaca, L. A.; Codognoto, L.; Machado, S. A. S.; Proc. Electrochem. Soc. 2002, 34.

139. Codognoto, L.; Machado, S. A. S.; Avaca, L. A.; Diamond Relat. Mater. 2002, 11, 1670.

140. Boye, B.; Brillas, E.; Marselli, B.; Michaud, P.A.; Comninellis, Ch.; Farnia, G.; Sandona, G.; Electrochim. Acta, in press.

141. Brillas, E.; Sirées, I.; Arias, C.; Cabot, P.L.; Centellas, F.; Rodriguez, R .M.; Garrido, J. A.; Chemosphere 2005, 58, 399

142. Canizares, P.; Lobato, J.; Paz, R.; Rodrigo, M.A.; Saez, C.; Water Res. 2005, 39, 2687.

143. Flox, C.; Garrido, J. A.; Rodriguez, R.M.; Centellas, F.; Cabot, P.L.; Arias, C.; Brillas, E.; Electrochim. Acta 2005, 50, 3685.

144. Panizza, M.; Cerisola, G.; Electrochim. Acta 2005, 51, 191.

Received: October 3, 2005

Published on the web: March 3, 2006 